\title{
Article
}

\section{Regional inequalities in the enlarged Europe}

\author{
Martin Heidenreich*, University of Bamberg, Germany
}

Summary In a multilevel system like the European Union (EU), social conflicts are defined and conceived mainly in territorial categories. As a result, the disparities between Eastern and Western Europe may give rise to additional transfer payments or even endanger further enlargements of the EU. The acuteness of this trilemma of enlargement, increased political cooperation and budgetary neutrality can be lessened either by a quick convergence of Eastern and Western performance levels, or by the differentiation of the regional employment and income situation in Central and Eastern Europe (CEE). The capital regions and the Western border regions in Central Europe are developing dynamically. Consequently, one can expect to see a relatively durable prosperity gap between Eastern and Western Europe, as well as increased regional differentiation within CEE. These differentiation processes could be a first step in transforming the definition of inequalities and interests into territorial and non-territorial forms of social inequalities. However, the relative stability of the European centreperiphery structure does not allow for the 'de-territorialization' of social relationships. Instead, there is evidence of a non-identical, path-dependent reproduction of long-established disparities.

Key words capital regions, centre-periphery structure, convergence, differentiation, enlargement, regional inequalities
Résumé Dans un système multi-niveaux comme l'Union européenne (UE), les conflits sociaux sont définis et conçus principalement en terme territoriaux. Les disparités considérables entre l'Europe de l'Est et de l'Ouest pourrait donner lieu à des transferts financiers additionnels considérables voire même mettre en danger de futurs élargissements. L'ampleur de ce trilème - élargissement, coopération politique accrue et neutralité budgétaire - peut être réduit soit par une rapide convergence des niveaux de performance ou par une différenciation de l'emploi régional et des revenus en Europe centrale et de l'Est (ECE). Les régions capitales et les régions à la frontière de l'UE se développent de manière très dynamique dès lors on peut s'attendre à ce que l'écart des prospérités entre l'est et l'ouest soit relativement durable en même temps que se produise une différenciation régionale accrue à l'intérieur de l'ECE. Ces processus de différenciation peuvent être interprétés comme un premier pas d'un processus dans lequel la définition des inégalités et des intérêts pourraient être transformés en formes territoriales et non territoriales d'inégalité sociale. Mais la relative stabilité de la structure européenne centrepériphérie ne permet pas une 'déterritorialisation' des relations sociales. A la place, il y a des preuves d'une reproduction non identique et 'path dependant' des disparités établies.

\footnotetext{
* Author to whom correspondence should be sent: Martin Heidenreich, University of Bamberg, D-96045

Bamberg, Germany. [email: martin.heidenreich@sowi.uni-bamberg.de] 


\section{Introduction}

Ten European countries, most of them Central European, with $75 \mathrm{~m}$ inhabitants will probably join the European Union (EU) in May 2004: (Southern) Cyprus, the Czech Republic, Estonia, Hungary, Latvia, Lithuania, Malta, Poland, Slovakia and Slovenia. The accession of Bulgaria and Romania is planned for 2007. The EU will decide in 2004 whether it will open accession negotiations with Turkey. This enlargement, the fifth of its kind, is the result of a long transition period in which the political and economic separation of Eastern and Western Europe has gradually been reduced. ${ }^{1}$ The membership perspective served as an external anchor and helped the post-socialist countries in Central and Eastern Europe (CEE) overcome the dilemmas associated with the fundamental and simultaneous transformation of their economic, political and sometimes even national order (Elster et al., 1998; Kitschelt et al., 1999; Stark and Bruszt, 1998). This political reunification of Europe was, to a large extent, also due to the work of the European Commission. It succeeded in cementing the invitation of the European Council of Copenhagen (1993) to join the EU - which was initially understood only as political rhetoric (Schimmelfennig, 2001) - by precise criteria and with a road map that clearly defined the obligations the post-socialist countries had to meet in order to accede to the EU.

However, the complementary reform of the $\mathrm{EU}$, its institutional architecture and its redistributive policies (especially the regional and agricultural policy) has failed up to now. The necessity and the difficulties of these institutional and political reforms point to a problem that is insufficiently taken into account in terms of its possible impacts on the future of the EU: the enormous prosperity gap between Eastern and Western Europe (cf. Bachtler and Downes, 2000; Dunford and Smith, 2000; Sokol, 2001). For example, the need for fundamental reform of the structural and agricultural policies, for which approximately 80 percent of the EU budget is used, is crucially influenced by this prosperity gap. This is most evident in the case of the structural funds. The regions with an average per capita gross domestic product of less than 75 percent of the EU average (Objective 1 regions) are the ones which mainly profit from these funds. The accession of the 10 candidate countries will increase the population in the corresponding regions from $66 \mathrm{~m}$ to $112 \mathrm{~m}$. Since the average Gross Domestic Product (GDP) per capita in the enlarged Union will shrink by approximately 13 percent, only $45 \mathrm{~m}$ of them (40 percent) will live in one of the current member states. The structural funds may therefore become a major instrument in the redistribution of financial aid from current to the new member states. If the EU does not successfully reform the system, the same will be true for the common agricultural policy (CAP). There are currently $6.8 \mathrm{~m}$ active farmers in the present member states, comprising 4.3 percent of total employment. In comparison, the 10 accession states employ a considerably larger number of farmers: $8.9 \mathrm{~m}$, comprising 20.7 percent of total employment. Therefore, if the current policies remain unchanged, this flow of funds will be redirected from the current to the acceding member states (especially after 2013 when the new members will be completely included in the CAP).

The increased pressure for redistributive policies reflects the fact that the economic performance of the presumably 10 new member states currently amounts to only 44 percent of the EU average (Table 1). These figures are lowest in Turkey, with 22 percent; Romania, with 25 percent; and Bulgaria, with 28 percent. The unemployment rates and the share of agricultural employment are much higher, and the share of the service sector is much lower, in the potential accession states than in the European Union. Another indicator for these regional differences is the so-called 'decile ratio'. The decile ratio is the proportion of the values which limit the lower and the upper decile of a distribution. The ratio of economic performance per capita will increase 
Table 1 The acceding countries and the member states of the European Union in comparison (2000)

\begin{tabular}{|c|c|c|c|c|c|c|c|c|c|c|}
\hline & \multicolumn{5}{|c|}{ Mean } & \multicolumn{5}{|c|}{$\begin{array}{c}\text { Decile ratio of regional disparities } \\
(\text { (P90/P10; weighted })^{a}\end{array}$} \\
\hline & $E U$ & $A C$ & $A C$ & $E U$ & $E U$ & $E U$ & $A C$ & $A C$ & $E U$ & $E U$ \\
\hline & $15^{\mathrm{b}}$ & $10^{c}$ & $12^{\mathrm{d}}$ & $25^{\mathrm{e}}$ & $27^{\mathrm{e}}$ & $15^{\mathrm{b}}$ & $10^{\mathrm{c}}$ & $12^{\mathrm{d}}$ & $25^{\mathrm{e}}$ & $27^{e}$ \\
\hline GDP per capita (PPS) & & & & & & & & & & \\
\hline EU15 $=100 \%{ }^{\mathrm{f}}$ & 100.0 & 43.7 & 38.0 & 90.7 & 86.5 & 2.0 & 1.9 & 2.8 & 3.1 & 3.8 \\
\hline Unemployment rate $(\%)$ & 8.4 & 15.5 & 12.4 & 9.6 & 9.3 & 4.5 & 3.7 & 3.7 & 4.6 & 4.7 \\
\hline $\begin{array}{l}\text { Employment rate (employees } \\
\text { in } \% \text { of the population } \\
\text { aged } 15-64 \text { years) }\end{array}$ & 63.8 & 58.4 & 60.8 & 62.8 & 63.2 & 1.4 & 1.3 & 1.5 & 1.4 & 1.4 \\
\hline $\begin{array}{l}\text { Agricultural employment } \\
\text { (\% of total employment) }\end{array}$ & 4.3 & 17.6 & 21.6 & 6.5 & 8.0 & 13.6 & 6.1 & 11.9 & 13.8 & 21.6 \\
\hline Industrial employment (\%) & 28.9 & 31.0 & 31.7 & 29.8 & 29.5 & 2.0 & 1.7 & 2.0 & 2.1 & 2.0 \\
\hline Service employment (\%) & 66.5 & 51.4 & 48.1 & 63.7 & 62.6 & 1.4 & 1.4 & 2.5 & 1.5 & 1.4 \\
\hline
\end{tabular}

Notes:

${ }^{a}$ The decile ratio of the economic performance per inhabitant is the GDP per capita of the region at the 90th percentile to the region at the 10th percentile. The figures refer to the 211 NUTS level- 2 regions of the EU and to the corresponding 55 regions in the accession countries. The decile ratios are weighted by the denominators of the respective indicators (inhabitants, economically active population, population aged 15-64 years, employment).

b EU15: The 15 member states of the European Union.

c AC10: 10 accession countries: The Czech Republic, Cyprus, Estonia, Hungary, Latvia, Lithuania, Malta, Poland, Slovakia and Slovenia.

$\mathrm{d}$ AC12: The 10 formerly mentioned accession countries and Bulgaria and Romania.

${ }^{\mathrm{e}}$ EU25 and EU27: The EU15 members and the respective 10 and 12 accession countries.

${ }^{\mathrm{f}}$ GDP per inhabitant (purchase power parity).

Sources: Own calculations on basis of European Commission (2002a; 2003).

from 2.0 to 3.8 in an enlarged Europe, if all 12 countries with which the Commission is currently negotiating join the EU in 2004 and 2007. When omitting Romania and Bulgaria, the average economic performance per capita of the most prosperous European (subnational) regions will be three times as high as in the poorest regions.

This widening of regional disparities in the EU, which are already larger than those in the USA (European Commission, 1996), could facilitate attempts to use political veto positions in order to obtain higher transfer payments, thus impeding reinforced political cooperation. This was a lesson learned after the southern enlargement (1981/86), which led to a considerable increase in structural funds (1987: 9 percent of the EU budget; 1992: 25 percent; cf. Allen, 2000); even though the southern countries already had a much higher GDP per capita. Increased redistribution struggles after enlargement may very well undermine attempts to increase political cooperation. Therefore, with the forthcoming enlargement, the EU is more frequently faced with the question of how political cooperation can be organized in a European multilevel system that is marked by considerable socioeconomic disparities, and in which social interests and identities are mainly defined in territorial terms. The answer to this question will determine whether the enlargement of the EU can be combined with closer political cooperation within the EU.

In the next section, we will develop the thesis that the EU will be confronted with a 
'trilemma' after the enlargement. This trilemma is that increased political collaboration, further rounds of enlargement and the continued marginal role of Europewide redistribution policies cannot be obtained at the same time. This trilemma can only be avoided if the national cleavages, which predominately shape the political processes and the current perceptions of social inequalities in the EU, are gradually supplemented by other territorial and non-territorial forms of social inequality thus moderating the political and social antagonism between rich and poor, Western and Eastern countries. An essential dimension of such a differentiation process can be regionally defined. A relatively homogeneous regional development within the different CEE states and within Eastern Europe will increase the difficulties of increasing political cooperation within the $\mathrm{EU}$; a differentiated development will facilitate this cooperation because such a development will undermine the definitions of compact and antagonistic national or CEE interests. Therefore, in the second section we will analyse the structure and development of regional inequalities in an enlarged Europe. Finally, we will briefly mention the historical dimension of these inequalities.

A region can be defined as a subnational territorial unit characterized by relatively homogeneous demographic, economic and sociocultural patterns and a governance structure. For the following empirical analyses, we will concentrate on the NUTS 2 and NUTS 3 regions of the current EU member states and on the corresponding regions in the accession countries. The nomenclature of territorial units for statistics (NUTS) established by Eurostat is a hierarchical classification that subdivides the member states of the European Union into 78 regions at NUTS level 1, 211 regions at NUTS level 2 and 1,093 regions at NUTS level 3. The United Kingdom, for example, is subdivided into 12 government office regions, 37 counties or groups of unitary authorities and 133 counties or local authority regions. A similar classification has been developed for the candidate countries (with the exception of Cyprus, Malta and Turkey). The 10 countries are subdivided into 53 level 2 regions. If Malta and Cyprus are added, 266 level 2 regions can be analysed ( 55 regions from the CEE countries and 211 from the EU-15 countries).

\section{Regional inequalities and the trilemma of the European enlargement}

Not every unequal distribution of resources and positions is a social inequality, since the diagnosis of social inequalities presupposes some form of social integration: '[U]nrelated positions do not compose a coherent social structure' (Blau, 1977: 5). For example, the grotesquely huge income differences in the world are hardly considered inequalities: 'The assumption is that the integration of various groups and strata in society cannot rest solely on their functional interdependence: it requires some actual social interaction among their members' (Blau, 1977: 5). Social differentiation without social integration will be denoted as disparity, otherwise as social inequalities or heterogeneity (depending on the existence or not of a rank order).

In an international context, different resource distributions are generally only considered as disparities. This points to an international order of sovereign states where the socio-economic situation of a population and its origins are generally associated with the internal affairs of the respective states. This can be interpreted as an incomplete 'Rousseauean transformation' of premodern understandings of inequalities. With his answer in 1755 to the question concerning the origins of inequalities between people, J. J. Rousseau (1993) assumed a natural equality of human beings. These equality norms are even now mainly limited to the political community of a nation. Uneven resource distributions are treated as social inequalities. This is 
mainly true for national states, but is also increasing in the European Union.

The importance that is attached to regional inequalities in a national context refers to the fact that states are monopolies of legitimate physical force within the borders of a demarcated territorial area (Weber, 1978). The territorial consolidation of the early European national states was a precondition for the transformation of territorial divisions into a functionally differentiated national space (Bartolini, 2000). This is a central thesis of the Norwegian social scientist Stein Rokkan (1999): the consolidation of external boundaries is a prerequisite for internal processes of economic, military-administrative and cultural differentiation. The territorial monopoly of modern states is threatened when the transformation from regional to functional interests does not take place, because the dissatisfaction with socio-economic disparities remains articulated in territorial categories as, for example, in inequalities between northern and southern, eastern and western, central and peripheral regions. Such a mobilization of territorially defined, socio-economic interests can easily be supported by regional ideologies or regionally based ethnic or religious identities.

Along this scale [interests, ideologies; identities: $\mathrm{MH}$ ], the perceived mutual dependency of the parties involved in conflict decreases; fair rules of competition and compatibility are harder to devise and more easily challenged; 'meeting half way' becomes an increasingly difficult and eventually positively nonsensical and outright despicable notion; the time frame becomes more extended. (Elster et al., 1998: 251)

In this case socio-economic differences are hardly susceptible any longer to pragmatic patterns of conflict negotiation and interest mediation. In addition, territorially defined minority positions are a threat to representative forms of democracies, since they undermine the legitimacy of majority decisions (Scharpf, 1999).
The inadequate meritocratic legitimacy of regional inequalities and their potential use for political mobilization against the central power explain why national states try to reduce regional inequalities through the politicaladministrative, legal and cultural homogenization of the national territory (Münch, 2001: 183). An alternative to the reduction of regional inequalities is their transformation into other, less disruptive forms of social inequalities; for example, into stratified or individualized patterns of stratification. Industrial relations, systems of social security and systems of mass education have thus increased the relative weight of class divisions in comparison to territorial-cultural divisions (Flora, 1999: 91). In both ways, most West European countries succeeded in transforming regionally based interests, ideologies and identities into individualized or collectively organized patterns of status competition and redistributive conflicts in most regions.

The EU is confronted with a similar challenge. Increased political cooperation in the EU depends on the fact that 'its citizens organize themselves more according to their social interests than according to national criteria, because national definitions of their positions will condemn them ... in principle and in a persistent way to a minority position' (ReeseSchäfer, 1999: 256). However, the EU is still a long way from such a redefinition of interests. Social inequalities are still perceived and represented mainly in territorial, and especially national categories. This reflects the logic of a multilevel system, in which territory is the crucial basis for the definition and articulation of socio-economic interests (Leibfried and Pierson, 1995).

The next enlargements of the EU will considerably intensify the problems associated with this territorial logic. From the accession date onwards, the disparities between Eastern and Western Europe can be articulated as territorial inequalities within the context of the EU (for example during the negotiations for the next EU budget 2007-13). If these new inequalities are not successfully transformed 


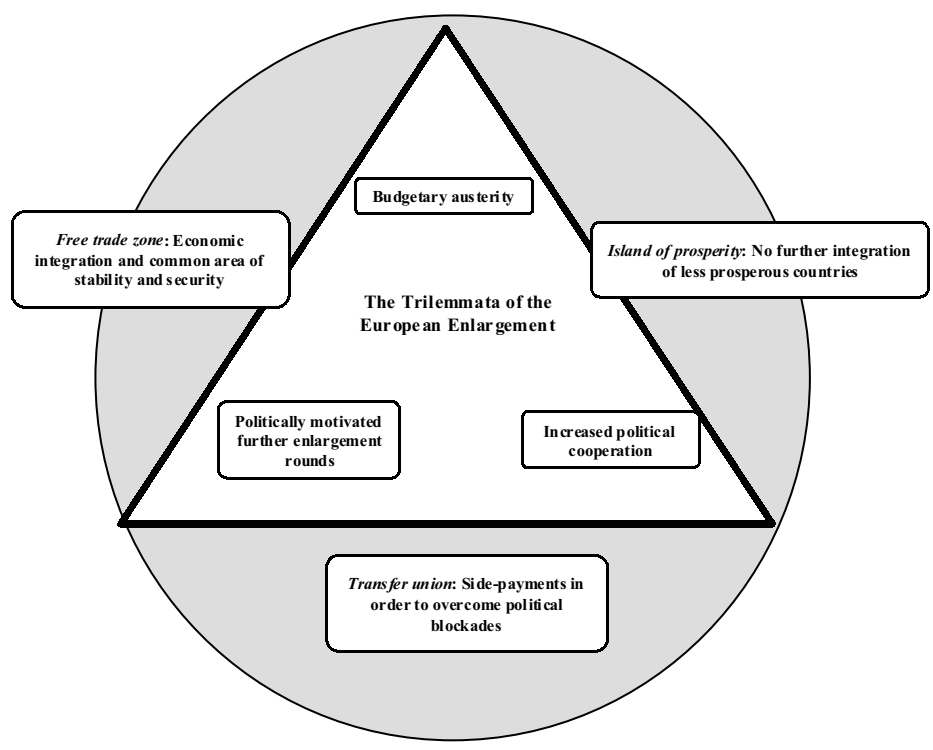

Figure 1 The European Union between budgetary austerity, enhanced political cooperation and enlargement

into other social - for example non-territorially defined - inequalities, the EU could fail due to the blockade potential of territorially defined interests, ideologies and identities. The EU would then be caught in a trilemma of budgetary austerity, increased political collaboration and politically motivated further rounds of enlargement (for example Turkey, Albania, Bosnia and Herzegovina, Croatia, Serbia, Macedonia, Turkish Cyprus, Moldova, Ukraine or Belarus). These three goals cannot be achieved simultaneously, even if they are intricately intertwined with each other. Either one or two will have to be sacrificed if the transformation of territorial inequalities into other social inequalities fails (see Figure 1).

First, an enlargement could only take place in the absence of additional transfer payments if the EU relinquished its hopes of increased political cooperation. Europe would be transformed into a free trade zone and perhaps a common area of stability and security. Second, further enlargements could be associated with reinforced political cooperation if the current EU budgetary limitations were clearly exceeded. Europe would move in the direction of a transfer union. Third, increased political cooperation could be attained without additional transfer payments if the EU were to abstain from the inclusion of poorer countries. In this case, the EU would become an island of prosperity in a politically unstable environment. These different logics of development can be combined to a certain extent.

In conclusion, in an international context, an uneven distribution of social goods, positions and opportunities ('disparities') cannot generally be considered as a sufficient indicator of social inequalities. Norms of equality and an internationally recognized and politically relevant rank order of socio-economic situations are hardly institutionalized on a global level. It is mainly in the context of a national state, disparities are considered and treated as inequalities. A national state, characterized by a territorially bound monopoly of 
legitimate physical force, has an essential interest in avoiding, reducing or redefining regional inequalities because if they crystallize into regional, potentially separatist ideologies and identities these inequalities may threaten the territorial integrity and sovereignty of a state. Therefore, national states try to reduce or transform regional inequalities in order to avoid a blockade of political processes. The EU is increasingly confronted with similar challenges. The next enlargements will transform disparities, which up until now could be treated as centre-periphery differences, into territorial inequalities within the context of a relatively closely integrated political community. Increased political cooperation within the EU will be possible after these enlargements only if the considerable territorial disparities between Eastern and Western Europe do not crystallize into stable and politically articulated regional inequalities. If the inequalities between Eastern and Western Europe fail to transform into other forms of social inequality, the EU will either have to provide considerable transfer payments in order to obtain the agreement of the poorer countries for the desired deepening of political cooperation, or it will have to relinquish hopes of closer political cooperation or of further enlargements.

Whether the EU really will have to face this trilemma of an economically integrated free trade zone, a politically integrated 'island of prosperity' or a socio-politically integrated transfer union, depends also on the process in which territorial disparities between Eastern and Western Europe are transformed into regional inequalities. Such crystallization is dependent on two conditions, which will be discussed in the next section. It will be explained that - in contrast to the situation at the national level - the possibility of avoiding this trilemma may paradoxically even increase with increased regional inequalities. Not all types of regional inequalities will impede closer political cooperation at the European level.

\section{Economic and labour market inequalities in an enlarged Europe}

Whether the enormous regional disparities within an enlarged EU will be politically articulated as regional and national inequalities also depends on the compactness and stability of national and regional interests and identity constructions. These can evolve in the course of the process of globalization and Europeanization. Based on Emile Durkheim, Richard Münch, for example, predicts a change from the traditional, mechanical forms of solidarity based on redistribution in the context of national states into more organic forms of solidarity in open, transnational spaces:

It can however be assumed that the remaining rest of mechanical solidarity will become smaller, less present and abstract, the more the division of labour increases and becomes more complex, and the more room for individuality is created by the increasing division of labour. That means that it must be smaller in a European society than in the different European nation-states ... the mechanical solidarity of the nationstates based on stronger external demarcation, internal homogenization, centralization and redistribution will be replaced by transnational organic solidarity based on individual exchange relationships ... organic solidarity consists of many dependency relations, it goes beyond national collectives and it supports the differentiation of these collectives. This type of solidarity is marked by stronger external connections and an increased internal differentiation. (Münch, 2001: 225, 274-5)

The reintegration of the CEE countries into the European space can therefore be analysed as a specific aspect of the Europeanization and globalization of economic interdependencies that, according to Münch, will weaken national patterns of social integration and coherence. 
On this basis, two complementary hypotheses - a convergence hypothesis and a differentiation hypothesis - can be formulated. First, the convergence hypothesis claims that if the East European economies develop very dynamically, the polarization between Eastern and Western European countries and regions is less likely than with a stable prosperity gap and a homogeneous, similarly poor income and labour market situation. A dynamic development of the CEE countries and regions could ease the trilemma of the eastern enlargement mentioned above.

However, this convergence hypothesis is not uncontested. It is challenged by dependency hypotheses that expect that the relationships between Eastern and Western Europe will be shaped by the long-term dependencies and centre-periphery structures which have evolved in the course of the last few centuries (Wallerstein, 1976). The relative explanatory power of the convergence and dependency hypotheses will be discussed immediately below.

Complementary to the increasing commonalities between national states - a consequence of the increasing exchange of goods, services and information - their internal differences, or their variety, may also increase (Münch, 2001: 197). If the CEE countries are characterized by increasingly differentiated economic and labour market structures, this may also reduce the compact confrontation of Eastern and Western interests. The EU would not be confronted by the relatively homogeneous national interests of less advanced countries, but by increasingly differentiated regional interests. Alternatively, based on Wallerstein's world-system theory, it can also be predicted that the peripheral situation of the CEE regions and countries will probably lead to a similarly weak economic structure. In this case, it can be predicted that the EU will have to face relatively homogeneous CEE situations and interests. The relative explanatory value of the differentiation and homogeneity theses will be examined later.

Given our interest in the socio-political implications of territorial inequalities, we will concentrate exclusively on inter-regional forms of social inequality, using mainly the economic performance per inhabitant (GDP) and unemployment rates as indicators. Intraregional forms of social inequality, which are another important source of differentiation (cf. Förster et al., 2002), are excluded from the analysis.

\section{Central and Eastern Europe in the context of the European division of labour}

After the collapse of the socialist regime, Eastern and Western Europe quickly began to converge in economic, political and military terms. The speed with which the orientation of the economic and political connections of the CEE countries with the West were reestablished after decades of close cooperation with other socialist countries is impressive. After the dissolution of the Soviet Union and the Council for Mutual Economic Assistance (1991), trade with Eastern neighbours suddenly broke down, while trade with Western countries resumed.

After the collapse of the socialist system, economic performance declined at first, reaching its lowest point between 1991 and 1993. From 1992 to 2000, the economy of the 12 accession countries grew faster than that of the EU $(+31$ percent in comparison to +16 percent). The highest growth rates were in Poland, Malta, Slovenia, Cyprus and Slovakia. Bulgaria, the Czech Republic, Lithuania and Romania experienced growth rates below the EU level. Even with current growth rates, it would take 130 years for the 12 acceding countries as a whole to reach the level of the current EU states. Slovenia would only take 34 years, while countries with lower growth rates would ceteris paribus never reach the EU level. The probability of a quick economic convergence between Eastern and Western Europe is consequently extremely small. 


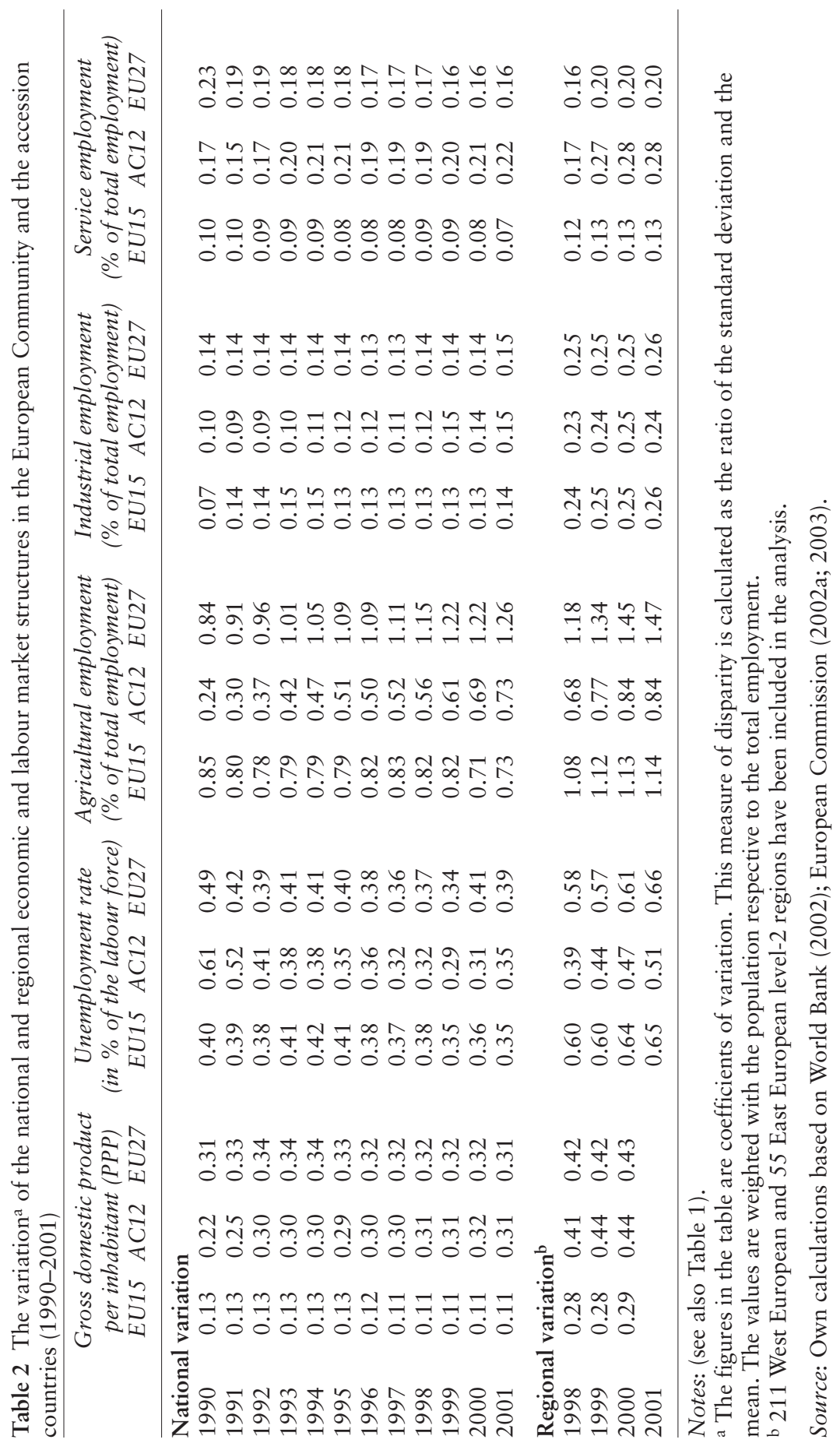


Other economic indicators point in the same direction (see Table 2). While the development of the regional and national GDP per capita in the current member states point to a certain convergence, the acceding countries have developed very differently since 1990 . This is documented by a clear increase in the regional and national coefficients of variation.

The variations of the national unemployment rates hardly differ between the EU and the acceding countries, with regional differences being higher in Western Europe. In the last few years, these differences have, however, clearly increased in Central and Eastern Europe. At national level a certain convergence can be observed for the 27 countries taken into consideration - but not at regional level.

The employment share of the service sector is rapidly increasing in the CEE economies. National and especially regional variety is increasing sharply in the course of this process. The central position of the Central European metropolis is reflected in high regional service sector employment, as well as in its increasing variation. The economic differentiation between urban and rural areas (Förster et al., 2002) also explains the high and strongly increasing variation of the employment shares in agriculture. The slightly increasing variation of the industrial employment share reflects a crucial feature of the post-socialistic transition processes; namely the shrinking and restructuring of the industrial sector.

Among the EU-27, there is currently no clear indication of a convergence if economic performance per capita, industrial employment or unemployment rates are taken into consideration. The diversity of employment shares in agriculture is increasing while the variation of employment in the service sector is decreasing. This means that the present national and regional disparities in Europe are not merely an intermediary phase on the way to an integrated Europe, but an indicator of a relatively stable division of labour in a reunited Europe.
The different patterns of regional specialization in Europe are an indicator of this new division of labour. These patterns can be reconstructed based on various cluster analyses of the regional data available (cf. also Heidenreich, 1998; Weise et al., 2001). The first step of such an analysis is the identification of the relevant variables (cf. Everitt et al., 2001). In a factor analysis of the available indicators for the 265 European NUTS 2 regions (excluding Malta), three factors emerge, which correlate strongly with the unemployment rate (2000), gross domestic product per capita (2000) and service sector employment share (2000). These variables are crucial indicators of the labour market performance and the economic specialization of European regions. In addition, the population density (2000) is included as an urbanization indicator.

In the next step, three highly specific regions (Brussels, Inner London, Ceuta y Melilla) are identified with the single-linkage method ('nearest neighbour') as outliers. In Table 3, the first two of these outliers are assigned to a residual category called 'global cities'.

Third, a cluster analysis of the standardized variables using the Ward algorithm is performed in order to identify an adequate number of clusters (cf. Backhaus et al., 2000). On the basis of the 'elbow-criterion', which states that the distance between the cluster centres decreases sharply after the fourth cluster, four clusters are identified. The dendrogram of this cluster analysis shows that the most advanced and the least developed regions, especially, are very heterogeneous. Therefore, it is also useful to take the next subclusters produced by the initial cluster analysis into account (see Table 3). This is, however, not possible with the k-means analysis, which would be otherwise preferred to the Ward algorithm (due to the possibility of revising the initial clustering). Given this, the regional structure of the European labour markets and economies can be described as follows: 
- Urban, generally metropolitan administration and service regions This group consists of wealthy urban agglomerations such as Berlin, Vienna, Ile de France (Paris), North and South Holland, Greater Manchester, London and Prague. These regions are characterized by a high population density and a prosperous, servicedominated economy. Inner London and Brussels constitute a separate class of global cities.

- Core industrial and service regions This very large group, with 152 regions, in which 56 percent of the European population produces 70 percent of total output, is characterized by a considerably lower population density, a relatively low service share and a low unemployment rate. Three East European capital regions - KözépMagyarország (Budapest), Bratislava and Bucharest - are assigned to this category.

- Peripheral, service-oriented regions with high unemployment rates This cluster includes the dismantled industrial regions within the current EU member states (in East Germany, Southern Italy, Spain and Finland), which are characterized by a high unemployment rate and a per capita GDP of approximately three-quarters of the EC average. Other subgroups within this category are the service-oriented regions in the West (for example, the French overseas départements and other Southern Italian regions). The third subgroup includes the CEE industrial regions, which are marked by even higher unemployment and lower economic performance (seen especially in Polish, Bulgarian and Slovak regions). The average unemployment rates in these regions have increased sharply in recent years.

- Peripheral industrial and agrarian regions with low unemployment rates The last cluster is composed of peripheral regions with a very low share of service employment and low unemployment rates. This group includes the agricultural regions of Greece, Spain and Portugal, but also the core industrial regions of the acceding countries. Many Czech regions, the Baltic countries and the most strongly industrialized regions of Hungary, Poland, Romania and Bulgaria fall into this group. The unemployment rates in these regions are much lower and the economic performance is much higher than in the formerly mentioned 'high-unemployment cluster' comprising Polish, Bulgarian and Slovak regions. The third subgroup mostly Romanian regions - is characterized by a low unemployment rate, a very high share of agricultural employees, and extremely low economic performance per inhabitant.

The enlarged European space is therefore characterized by an extraordinary heterogeneous mixture of prosperous metropolitan regions, service-dominated and industrialized regions and old industrial and agricultural regions (see Figure 2). While four-fifths of the Western European population lives in metropolitan, core industrial or tertiary regions, the same can be said for only 8 percent of the CEE population. There are currently $75 \mathrm{~m} \mathrm{EU}$ Europeans living in peripheral regions (mostly in the Mediterranean area and in East Germany). This total will increase by $172 \mathrm{~m}$ people after the accession of 12 new member states. Semi-peripheral industrial and agricultural regions dominate the CEE economic and labour market structure.

This can be interpreted as an indication of a relatively stable inner-European division of labour, in which most of the Central and Eastern European regions are relegated to a peripheral position. This division of labour as well as the comparative economic development of the last decade support the thesis that the economic differences between Eastern and Western Europe will only decrease very slowly. A quick convergence is not to be expected (cf. also Dunford and Smith, 2000; Sokol, 2001). The results mentioned above can rather be interpreted as an indicator for the non-identical reproduction of the centre- 


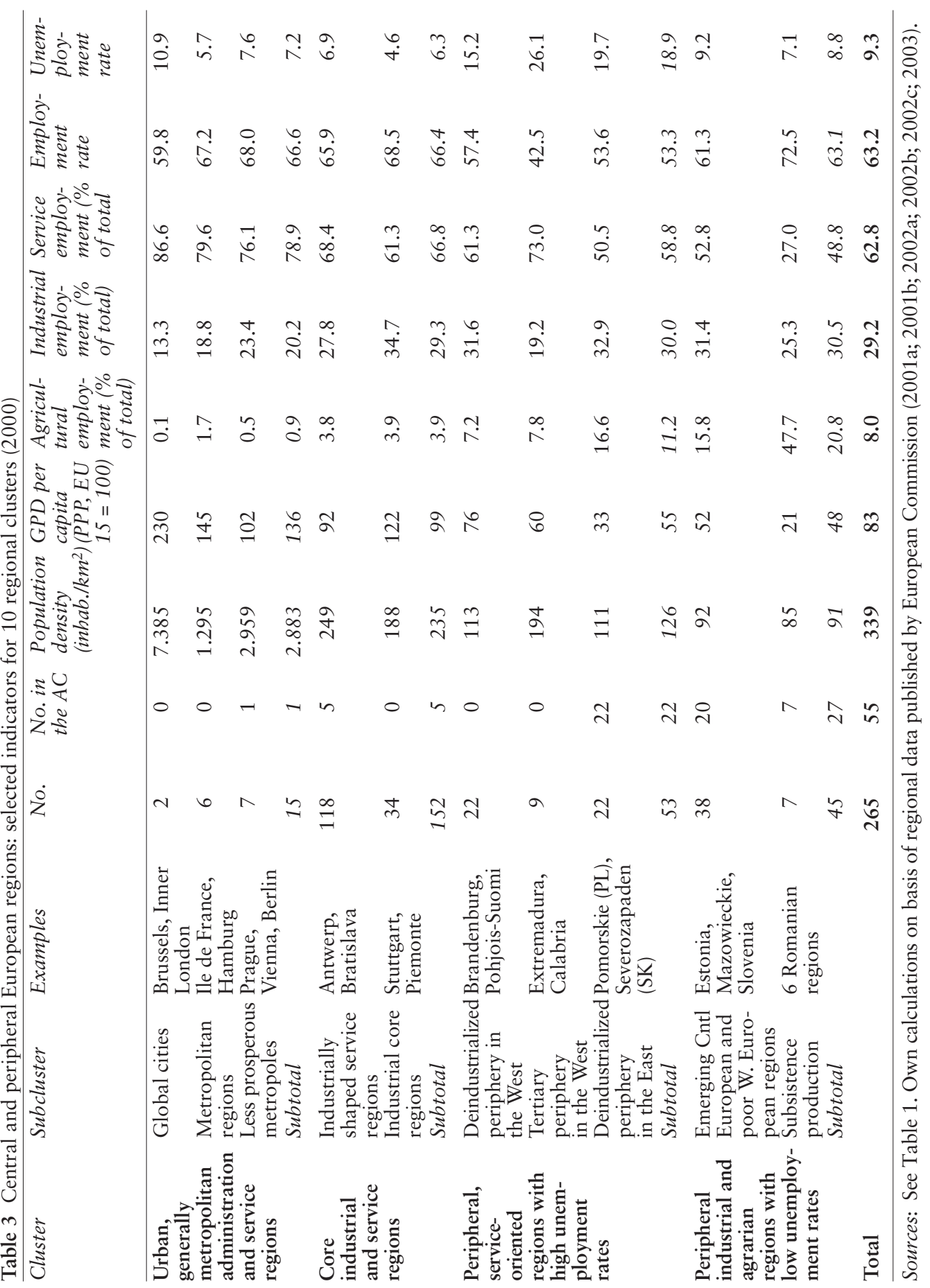




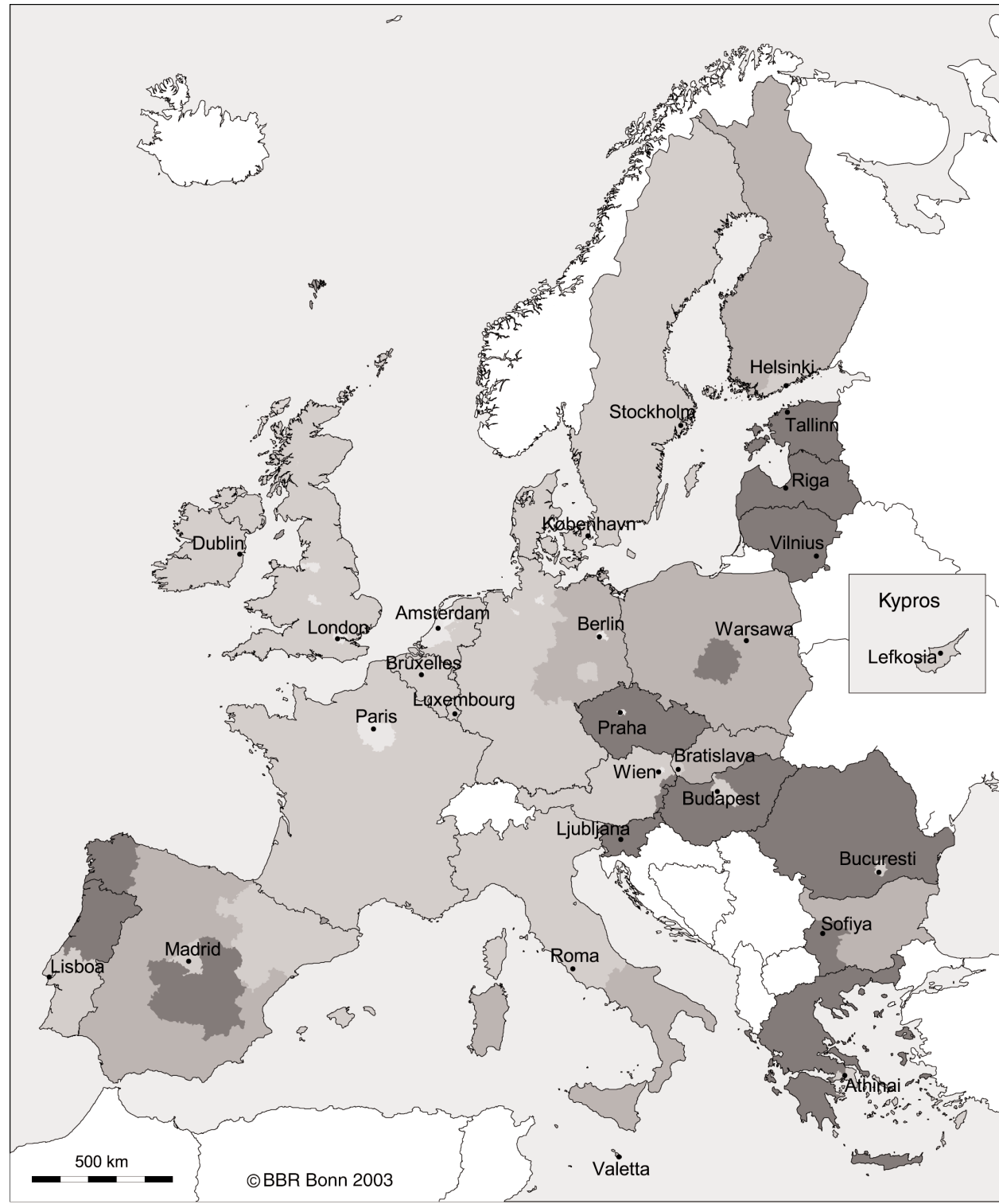

Regional types of central and peripheral economic regions

Urban, often metropolitan service regions

Core industrial and service regions

Peripheral regions with high unemployment

Peripheral industrial and agrarian regions with low unemployment
Area excluded from investigation

Figure 2 Central and peripheral regions in the enlarged Europe 
Table 4 Regional differences of economic performance (1995 and 1999)

\begin{tabular}{lccl}
\hline Country & $\begin{array}{c}\text { Ratio of the GDP per capita in the } \\
\text { most and the least developed NUTS } \\
\text { level-2 regions of a country }\end{array}$ & $\begin{array}{c}\text { The most developed NUTS } \\
\text { level-2 regions }\end{array}$ \\
\hline Bulgaria & 1995 & $\frac{2000}{158 \%}$ & Yugozapaden (Sofia) \\
Czech Republic & $161 \%$ & $158 \%$ & Prague \\
Hungary & $236 \%$ & $269 \%$ & Közép-Magyarszág (Budapest) \\
Poland & $202 \%$ & $240 \%$ & Mazowieckie (Warszawa) \\
Romania & $164 \%$ & $221 \%$ & Bucharest \\
Slovakia & $171 \%$ & $276 \%$ & Bratislava \\
\hline
\end{tabular}

Source: European Commission (2003).

periphery structures that have shaped Europe for centuries.

This is, however, only one side of the coin. This apparent homogeneity masks a considerable heterogeneity. Eight percent of the Central and Eastern European population lives in the most advanced urban regions, 34 percent in the relatively prosperous low employment cluster, 40 percent in the less prosperous high unemployment regions and the remaining 18 percent in the least prosperous agricultural regions of Romania. This may be the beginning of a differentiation between the Central and Eastern European regions.

\section{The development of regional inequalities in Central and Eastern Europe}

Economic differences between the CEE countries were considerable, even under socialism (Gorzelak, 1996: 41). After the fall of socialism, these differences became greater (cf. Table 2). A similar development could be expected on the regional level. On the basis of other studies (cf. Bachtler and Downes, 2000; Dunford and Smith, 2000; Sokol, 2001), it can be predicted that urban service regions and western border regions will generally be among the winners in the transition processes; while old or mono-industrially structured regions dominated by one company, and eastern border regions, will be on the losing side. In fact, the economic performance of the eastern border regions is 29 percent lower than the CEE average, while the western border regions exceed this level by 10 percent, as well as the capital regions by 61 percent. But it is unclear if this result simply reflects the better performance of Central European countries in comparison to the Eastern European ones or if it is an indicator of increasing regional differentiation within the context of the same country. In the first case, the EU will be confronted with the homogeneous national interests of 10 relatively poor countries. In the second case, the political impact of the prosperity gap between East and West will be weakened by regional differentiation processes. First we will look at this question compared with existing literature on the topic. Then we will analyse the available statistical evidence.

Urban, service-dominated regions - consisting mainly of capitals, but also other regional centres like Poznan, Krakow, Wroclaw, Gdansk and Szczecin - have been the main benefactors of reintegration into the capitalist world economy. This is demonstrated by the positive economic developments in the last few years. In the countries with many NUTS level-2 regions, the capital region is the richest one, and in most of the countries (with the exception of Bulgaria and Slovakia) the regional variation has sharply increased in recent years (see Table 4). The Central European capital regions are the clear winners of the post-socialist transition and integration processes. The expanding service activities, as well as most of the foreign direct investments, 
Table 5 National impact on the regional economic structures in the 12 accession countries. Explained variance

\begin{tabular}{ccccccc}
\hline & $\begin{array}{c}\text { Employment } \\
\text { rate }\end{array}$ & $\begin{array}{c}\text { Unemployment } \\
\text { rate }\end{array}$ & $\begin{array}{c}\text { GDP per } \\
\text { capita (PPS) }\end{array}$ & $\begin{array}{c}\text { Share of } \\
\text { agricultural } \\
\text { employment }\end{array}$ & $\begin{array}{c}\text { Share of } \\
\text { industrial } \\
\text { employment }\end{array}$ & $\begin{array}{c}\text { Share of } \\
\text { service } \\
\text { employment }\end{array}$ \\
\hline 1995 & & & $60 \%$ & & & \\
1998 & $58 \%$ & $63 \%$ & $53 \%$ & $(61 \%)$ & $(45 \%)$ & $(35 \%)$ \\
1999 & $62 \%$ & $67 \%$ & $53 \%$ & $64 \%$ & $43 \%$ & $58 \%$ \\
2000 & $63 \%$ & $74 \%$ & $46 \%$ & $67 \%$ & $35 \%$ & $59 \%$ \\
2001 & 60 & & $68 \%$ & $42 \%$ & $60 \%$ \\
\hline
\end{tabular}

Notes: The table is the result of a one-way analysis of variance of the 55 NUTS level-2 regions of the 12 accession countries. It contains the share of the variance that can be explained by the national affiliation of the region. For example, in 2001 the error in the estimation of the regional employment rate can be reduced by $63 \%$ if the nationality of the region is known - and not only the fact that the region belongs to the accession countries. Figures in parentheses: these are not reliable due to an elevated number of missing values.

also contribute to the revaluation of the capitals (cf. Bachtler et al., 2000: 360; Fassmann, 1997: 27; Williams and Balaz, 1999: 183). Thus, the CEE capital regions (with the exception of Sofia) are developing into interfaces between global and national production networks. A CEE city belt in the shape of a boomerang seems to be emerging from Warsaw, over Prague, Bratislava and Vienna, to Budapest (cf. Gorzelak, 1996: 127).

The western border regions or, in the case of Greece and Austria, the southern border regions, could also profit from reintegration into the European economic area. This is especially true for the Polish, Czech, Slovak, Slovenian and Hungarian border regions, which are becoming preferred locations for Western firms. Examples include the Audi manufacturing plant in Györ, the GM plant in Saint Gotthard, the Škoda plant in Mladá Boleslav and the VW plant in Bratislava, to name but a few.

Many industrialized regions, however, are among the losers in the transformation process. Numerous, old and mono-industrial regions are in a critical condition, especially if they had specialized in coal, iron, steel and arms under the socialist economy. Examples include: north-eastern Hungary, especially Ózd; Starachowice in Poland's south-eastern region; Kladno in the Czech Republic; Kato- wice, Lódz and Walbrzych in Poland; Baranya in Hungary, and many Slovak industrial regions. The large companies, which were created according to the socialist industrialization model and often completely dominated a region, could not resist market pressures in the changed economic environment. Given the way the respective economic and labour market indicators have developed, it does not seem as if Central European industrial regions will be able to emerge as the crystallization point of a dynamic economic development by means of displacing plants in West Europe.

The eastern regions at the borders of the Ukraine and Belarus are also among the losers in the transformation and reintegration process. 'These eastern border regions represent a new periphery' (Fassmann, 1997: 30f). This gap between western and eastern regions will increase even more with Eastern enlargement, since the visa-free border traffic between Poland and its eastern neighbours will then be abolished.

However, based on a one-way analysis of variance (see Table 5), it can be shown that the economic performance, the economic structure and the labour market performance of a region in a given accession country are above all determined by the development of the respective country. Even in the last few 


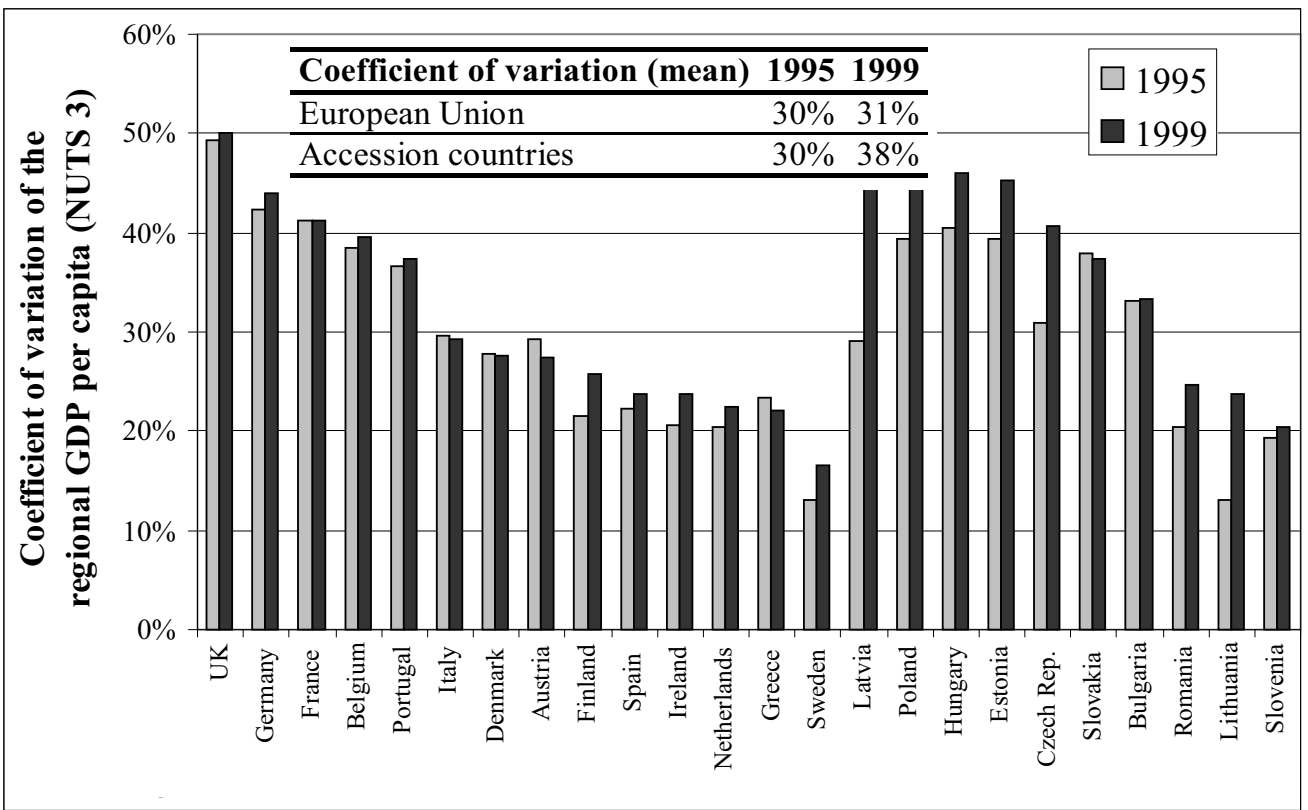

Figure 3 Regional variation of the economic performance in the EU and the accession countries (1995 and 1999; NUTS level-3 regions)

Source: European Commission (2002c).

years the national impact (the variance explained by the 'nationality' of a region) has increased for most of the indicators listed in Table 5. After the end of socialism, the newly established institutions of the CEE countries have had a strong and increasing impact on the transformation of the regional economic and labour market structure.

The gross domestic product (GDP) per capita at the national level has a low and steadily decreasing influence on the GDP per capita on the regional level. This is a clear indication of a regional differentiation in Eastern European countries, which could contribute to the weakening of territorial differences within the EU. The increasing variation of the regional GDP per capita (NUTS level 3) points in the same direction. In only four years the coefficient of variation in the 12 accession countries increased from 30 percent (the level of the current EU member states) to
38 percent (see Figure 3). This reflects the impact of a single differentiating factor. Only the capital regions perform much better than their countries as a whole. The level of regional inequalities, omitting the richest region, is much lower (between 5 percent in Estonia and 28 percent in Poland). Whether a region is a border region to one of the $15 \mathrm{EU}$ countries or to the succession states of the USSR has - in comparison to the national mean - only a marginal impact on the economic performance of a region. Two partially opposing forces therefore shape the socioterritorial structure of Central and Eastern Europe: on the one hand, the increasing role of the national state; and on the other hand, the increasing tension between urbanized, mostly metropolitan service regions, and industrialized or even agrarian regions. The second development is reminiscent of the classic contrast between urban networks and 
rural alliances, which according to Rokkan (1980: 121) have shaped the East European periphery since the 16 th century.

In this section, the relative explanatory powers of the convergence and dependency theses, and the differentiation and homogeneity theses, have been discussed. The results can be summarized as follows: the slow reduction of economic differences between Eastern and Western Europe can hardly be interpreted as a confirmation of the convergence thesis. Instead, the economic structure of a small number of service regions, many agrarian and old industrial regions and a considerable number of better developed (although still peripheral) industrial regions, supports the thesis of a non-identical reproduction of the traditional centre-periphery relationships between Eastern and Western Europe. Even if the economic disparities between Eastern and Western Europe do decrease, a path-dependent, nonidentical reproduction of current patterns of industrialization and dependency is more likely than a mere convergence towards a single European-capitalism model (see, for the thesis of Central European network capitalism, Wilderer, 2002).

The differentiation thesis correctly predicts the different developments of the CEE countries and the dynamic development of the capital regions. Without the capital regions, the economic inequalities within these countries are relatively low - with the exception of Poland, where the variation in economic performance even without the richest region is nearly as high as in Italy (European Commission, 2002c: 53). Given this evidence, it is hard to predict whether or not the socio-economic situation of the CEE states will be sufficiently homogeneous to be articulated effectively through the respective national states in the coming decades. In the short run, it can be confidently assumed that the enormous regional inequalities between Eastern and Western Europe will shape the European Union in the sense of the aforementioned trilemma. In the next decades, however, a slowly increasing cohesion between East and West and increasing differentiation within the Eastern (as well as Western) European countries will reduce the starkness of the opposition between a prosperous West and a poor East. While this may facilitate political and economic cooperation in the framework of the EU, it will also change the nature of the European Union. Given the high level of regional inequalities within the current (but especially within the enlarged) Europe, the current patterns of cooperation between autonomous and relatively homogeneous national states may be successively supplemented by crossboundary networks between highly developed regional economies. Such a European 'World of Regions' (Scott, 1998) would reproduce the polycentric structure of the premodern and prenational economic geography of Europe. In the next section, crucial aspects of this pattern will briefly be outlined.

\section{A note on European differences in historical perspective}

Territorial differences in economic capabilities prove to be extraordinarily durable. The probability of a 'de-territorialisation of the social' (Beck, 1999) is therefore very low. The centreperiphery structures analysed above are, in a sense, the archive of European economic and social history, in which past dependencies, conflicts and patterns of the division of labour are 'stored'. This relative stability of spatial structures should be reconstructed by a short retrospective look at the period between the 13th and 16th centuries, since it is in this period that European centre-periphery structures developed and consolidated. Such a retrospective view may be a useful antidote to hasty convergence and de-territorialization theses.

Economic dynamics in Europe are traditionally concentrated in a city belt stretching from northern Italy over western Germany and the Benelux countries to southern England. The Mediterranean countries and the northern, 
western and eastern European regions were situated on the margin of European development. As early as the 13th century, it was this European city belt that emerged along the revived long-distance trade routes between the southern and northern poles of the European world economy which shaped European development. This urbanized European core region, whose economic centre began slowly shifting from Italy to Northern Europe in 1600 (Braudel, 1992), is the area in which innovations and economic growth have been concentrated in Europe since the Middle Ages. This Western European city belt played a crucial role in the development of trade capitalism and the Western European system of states, while for much longer Central and Eastern Europe was characterized by agrarian structures and empires.

According to Stein Rokkan (1999), this city belt played a crucial role in the territorial structure of Europe. He demonstrates that this network of autonomous cities became the economic as well as political centre of the new Europe. Politically speaking, this city belt contributed to the contrast between federal and centralistic structures. While the core region of the continent was shaped by weakly integrated federal structures (for example the Roman Empire of German Nations and later the North German Association, Switzerland and the United Netherlands), more strongly integrated political structures could emerge at the edges of the city belt. While federal national states developed in the European core region, military-based empires and stateempires - e.g. the Habsburg Dynasty, the Ottoman Empire or Prussia and Russia dominated the political structure of Central and Eastern Europe.

Wallerstein (1976) emphasizes that the Eastern European peculiarities (weaker cities, a huge proportion of unused land, weaker territorial rulers as a consequence of the invasion of the Turks and Mongolian Tartars), until the 15 th century constituted only a minimal advantage for Western European development. The minimal initial differences were succes- sively increased in the context of the European world economy that emerged between 1450 and 1640. Central and Eastern Europe's role was reduced to that of the raw material producer for the industrializing West. It specialized in the export of grain, wood and wool. This is especially true for the Polish wheatexporting economy. This agricultural specialization delayed the development of a diversified high-value-added economy and delayed the development of the urban bourgeoisie. While Western Europe developed labour markets as central institutions of a capitalist economy, the CEE economy was relegated to the position of 'coerced cash-crop labour'.

Many of the previously described characteristics of the CEE economies were established centuries ago. First, there is the high proportion of agricultural production that reflects the delayed industrialization of most CEE countries and their former role as the granary of Western Europe. Second, there is a relatively poorly developed and capital-centred system of cities. Most CEE countries are dominated by a single urban agglomeration, whereas polycentric structures such as those in Germany, Switzerland, the Netherlands and Italy can only be found in Poland. Third, as early as the 16th century, an inner-European division of labour emerged, in which Central and Eastern Europe specialized in less valueadded-intensive products. Finally, Central and Eastern Europe has a considerable weight of ethnic minorities, which is the result of a legacy of multi-ethnic empires like the Habsburg, Russian and Ottoman empires. These four historic characteristics of CEE societies are relatively securely anchored in territorially based institutions, competences and identities. The relative stability of European centreperiphery patterns shows that there is no such thing as the 'de-territorialisation of the social'. This is an argument for the analysis of the non-identical, path-dependent reproduction of territorially based patterns of cooperation and dependency, and not for the unchangeable reproduction of past centre-periphery relations. 


\section{Conclusion: the EU at a crossroads}

In a multilevel system like the EU, social conflicts are predominantly defined according to territorial categories. Therefore, the increasing territorial inequalities in an enlarged Europe may create barriers in the struggle for closer political cooperation and demands for additional transfer payments. The trilemma of further enlargements, closer political cooperation and budgetary neutrality can only be avoided if some CEE regions develop in such a dynamic way that a polarization between Eastern and Western European interests can be reduced by an economic convergence between East and West or by an increasing differentiation within the CEE states themselves. Despite the higher rates of economic growth in Central and Eastern Europe, the reduction of the economic differences between East and West will be a very long process, and will take at least several decades. The increasing disparity between the CEE states, the dynamic development of the capital regions, as well as the slightly higher economic capabilities of the western border regions support the thesis of increasing differentiation in the economic and labour-market situation in Central and Eastern Europe.

Currently, the differences within these states may still be too insignificant to impede the articulation of relatively uniform national interests. In the short term, the territorially defined interests of the CEE states will therefore play a crucial role in shaping the immediate future of the EU. The EU will not be able to completely avoid the above-mentioned trilemma and the corresponding alternatives of a transfer union, an island of prosperity, or a predominantly economically integrated free trade zone. European social policy (especially in the form of agricultural and regional policies) will be shaped by additional demands for redistributive policies. Increasing political cooperation may take the form of a Europe of differentiated speeds (cf. Vobruba, 2003) characterized by a more strongly politically integrated core or pioneer group, with the rest of the EU countries profiting mainly from the common market and eventually the common currency. Such a 'variable geometry', which would reproduce the centuries-old differences between a West European core region and a Mediterranean and East European periphery, could erode the reliability of the current institutional setting, thereby supporting the move towards a primarily economically integrated Europe and thus facilitating the integration of other neighbouring countries.

If the EU should, however, succeed in slowing down its expansion dynamics and avoiding the traps of a 'variable geometry' (a fragile and still territorially based form of cooperation), a gradual consolidation of new boundaries could be the basis for new internal processes of regional as well as functional differentiation and structuration. The current European divisions, which are mainly defined in national terms, could, during this process, be gradually transformed into other social divisions (for example: divisions between highly and poorly developed regions, between service and industrial regions and perhaps even as conflicts between the winners and losers of the processes of Europeanization and globalization). ${ }^{2}$ Such a shift from national to regional and other social divisions may require new forms of social security, and solidarity would need to be based less on redistribution and more on the enhancement of individual and regional capabilities (for example, through the political stimulation of industrial and regional modernization processes). The development of innovation-enhancing institutions and the shaping of regional, national and transnational innovation regimes may become a feature of future European social policy, which contributes ex ante - not only ex post, through redistributive policies - to the reduction of economic inequalities in the enlarged Europe.

\section{Acknowledgements}

For suggestions and criticism I would like to thank Jürgen Friedrichs, Ian Gough, Richard Münch and Mirka Wilderer. The graphical 
transposition of the cluster analysis (Figure 2) was provided by Karl Peter Schön (Federal Office for Building and Regional Planning, Bonn).

\section{Notes}

1 In this article, the expression 'Eastern and Western Europe' is taken as a short formula for Central and Eastern Europe (CEE) and the Balkans (South-eastern Europe) on the one hand and the $15 \mathrm{EU}$ and the four EFTA (European Free Trade Association) countries on the other hand. Our statistical data are limited to the EU and the accession countries.

2 The economic and political transition and integration of the East European countries clearly increases the social inequalities in most of these countries: the Gini-coefficient of the income inequality increased in the Czech Republic from 0.21 (1992) to 0.26 (1996), in Hungary from 0.28 (1991) to 0.32 (1994) and in Poland from 0.27 (1992) to 0.29 (1999) [source: www.lisproject.org; accessed on 15 February, 2003].

\section{References}

Allen, D. (2000) 'Cohesion and the Structural Funds', in H. Wallace and W. Wallace (eds) Policy-making in the European Union, 4th edn, pp. 243-65. Oxford and New York: Oxford University Press.

Bachtler, J. and Downes, R. (2000) 'The Spatial Coverage of Regional Policy in Central and Eastern Europe', European Urban and Regional Studies 7 (2): 159-74.

Bachtler, J., Downes, R. and Gorzelak, G. (2000) 'Transition, Cohesion and Regional Policy in Central and Eastern Europe. Conclusions', in J. Bachtler, R. Downes and G. Gorzelak Transition, Cohesion and Regional Policy in Central and Eastern Europe, pp. 355-78. Aldershot: Ashgate.

Backhaus, K., Erichson, B., Plinke, W. and Weiber, R. (2000) Multivariate Analyseverfahren. Berlin: Springer.

Bartolini, S. (2000) 'Old and New Peripheries in the European Processes of Territorial Expansion', Working Paper No. 2000/153, Florence. [www.march.es/NUEVO/IJM/CEACS/ PUBLICACIONES/WORKING\% 20PAPERS/ 2000_153.pdf; requested on 2 February, 2003].

Beck, U. (1999) 'Globalisierung als Unterscheidungsmerkmal der Zweiten Moderne', in G. Schmidt and R. Trinczek (eds) Globalisierung, pp. 53549. Baden-Baden: Nomos.
Blau, P. M. (1977) Inequality and Heterogeneity: a Primitive Theory of Social Structure. New York: Free Press.

Braudel, F. (1992) The Perspective of the World: Civilization and Capitalism 15th-18th Century, Vol. 3. Berkeley: University of California Press.

Dunford, M. and Smith, A. (2000) 'Catching Up or Falling Behind? Economic Performance and Regional Trajectories in the "New Europe", Economic Geography 76 (2): 169-95.

Elster, J., Offe, C. and Preuss, U. K. (1998) Institutional Design in Post-Communist Societies: Rebuilding the Ship at Sea. Cambridge: Cambridge University Press.

European Commission (1996) 'First Report on Economic and Social Cohesion 1996'. Luxembourg: Office for Official Publications of the European Communities.

European Commission (2001a) 'Unity, Solidarity, Diversity for Europe, Its People and Its Territory, Second Report on Economic and Social Cohesion', Luxembourg. [www.inforegio.cec.eu.int/wbdoc/ docoffic/official/repor_en.htm; requested on 2 February, 2003].

European Commission (2001b) Regions: Statistical Yearbook 2001. Luxembourg: Office for Official Publications of the EC.

European Commission (2002a) 'First Progress Report on Economic and Social Cohesion', Brussels, $\operatorname{COM}(2002) 46$ final.

European Commission (2002b) Statistical Yearbook on Candidate and South-east European Countries - Data 1996-2000. Luxembourg: Office for Official Publications of the European Communities.

European Commission (2002c) Regions: Statistical Yearbook 2002. Luxembourg: Office for Official Publications of the EC.

European Commission (2003) 'Second Progress Report on Economic and Social Cohesion', Brussels, $\operatorname{COM}(2003)$ 34/4.

Everitt, B. S., Landau, S. and Leese, M. (2001) Cluster Analysis, 4th edn. London: Arnold.

Fassmann, H. (ed.) (1997) Die Rückkehr der Regionen. Beiträge zur regionalen Transformation Ostmitteleuropas. Wien: Österreichische Akademie der Wissenschaften.

Flora, P. (1999) 'Introduction and Interpretation', in S. Rokkan State Formation, Nation Building, and Mass Politics in Europe. The Theory of Stein Rokkan; based on His Collected Works (ed. by P. Flora). Oxford: Oxford University Press.

Förster, M., Jesuit, D. and Smeeding, T. (2002) 'Regional Poverty and Income Inequality in Central and Eastern Europe: Evidence from the Luxembourg Income Study', LIS Working Paper No. 324 [http://www.lisproject.org/publications/ liswps/324.pdf; requested on 2 February, 2003] 
Gorzelak, G. (1996) The Regional Dimension of Transformation in Central Europe. London: Kingsley.

Heidenreich, M. (1998) 'The Changing System of European Cities and Regions', European Planning Studies 6 (3): 315-32.

Kitschelt, H., Mansfeldova, Z., Markowski, R. and Tóka, G. (1999) Post-Communist Party Systems: Competition, Representation, and Inter-party Cooperation. Cambridge: Cambridge University Press.

Leibfried, S., and Pierson, P. (eds) (1995) European Social Policy: Between Fragmentation and Integration. Washington, DC: Brookings Institution Press.

Münch, R. (2001) Offene Räume. Soziale Integration diesseits und jenseits des Nationalstaats. Frankfurt a. M.: Suhrkamp.

Reese-Schäfer, W. (1999) 'Supranationale oder transnationale Identität. Zwei Modelle kultureller Integration in Europa', in R. Viehoff and R. T. Segers (eds) Kultur, Identität, Europa, pp. 253-66. Frankfurt a. M.: Suhrkamp.

Rokkan, S. (1980) 'Eine Familie von Modellen für die vergleichende Geschichte Europas', Zeitschrift für Soziologie 9 (2): 118-28.

Rokkan, S. (1999) State Formation, Nation Building, and Mass Politics in Europe. The Theory of Stein Rokkan; Based on His Collected Works (ed. by P. Flora). Oxford: Oxford University Press.

Rousseau, J-J. (1993) [1755] Discourse on the Origins of Inequality: Polemics, and Political Economy (Collected Writings of Jean Jacques Rousseau, Vol. 3). Lebanon, NH: University Press of New England.

Scharpf, F. W. (1999) Governing in Europe. Effective and Democratic? Oxford: Oxford University Press.

Schimmelfennig, F. (2001) 'The Community Trap: Liberal Norms, Rhetorical Action, and the Eastern Enlargement of the European Union', International Organization 55 (1): 47-80.
Scott, A. J. (1998) Regions and the World Economy. The Coming Shape of Global Production, Competition, and Political Order. Oxford: Oxford University Press.

Sokol, M. (2001) 'Central and Eastern Europe a Decade after the Fall of State-Socialism: Regional Dimensions of Transition Processes', Regional Studies 35 (7): 645-55.

Stark, D. and László, B. (1998) Postsocialist Pathways: Transforming Politics and Property in East Central Europe. Cambridge: Cambridge University Press.

Vobruba, G. (2003) 'The Enlargement Crisis of the European Union: Limits of the Dialectics of Integration and Expansion', Journal of European Social Policy 13 (1): 35-49.

Wallerstein, I. (1976) The Modern World-system: Capitalist Agriculture and the Origins of the European World-economy in the Sixteenth Century. New York: Academic Press.

Weber, M. (1978) Economy and Society: an Outline of Interpretive Sociology (ed. by G. Roth and C. Wittich). Berkeley and London: University of California Press.

Weise, C., Bachtler, J., Downes, R., McMaster, I. and Toepel, K. (2001) 'The Impact of EU Enlargement on Cohesion'. Final report. Berlin and Glasgow, March 2001 [http://europa.eu.int/ comm/regional_policy/sources/docgener/studies/p df/enlarge.pdf; requested on 2 February, 2003].

Wilderer, M. (2002) National Production Regimes in Post-Socialist Countries. The Case of the Czech Republic. Frankfurt a. M.: Peter Lang.

Williams, A. M. and Balaz, V. (1999) 'Transformation and Division in Central Europe', in R. Hudson and A. M. Williams (eds) Divided Europe. Society and Territory, pp. 163-85. London: Sage.

World Bank (2002) World Development Indicators. Washington: World Bank. 